\section{Evaluation of Capsicum Germplasm for Sources of Resistance to Rhizoctonia solani}

\author{
Rejah Muhyi ${ }^{1}$ and Paul W. Bosland ${ }^{2}$ \\ Department of Agronomy and Horticulture, New Mexico State University, Las \\ Cruces, NM 88003
}

Additional index words. vegetable breeding, root rot, disease resistance, chile

\begin{abstract}
A reliable screening method to detect Rhizoctonia solani Kuhn resistance in chiles (Capsicum annuum L.) was developed using infested corn (Zea mays Bonaf.) kernels as inoculum. The most aggressive New Mexican isolate of $R$. solani (PWB-25) was used to screen 74 Capsicum accessions for resistance to root rot caused by the fungus. The accessions differed in resistance, with disease ratings ranging from 2.9 to 8.6 on a 0 (no disease) to 9 (seedling dead) scale. The percentage of resistant plants, those in the interaction phenotype index class $0,1,2$, and 3, ranged from $2.4 \%$ to $77.1 \%$. Nineteen accessions representing four species had $\geq \mathbf{5 0 \%}$ resistant individuals and would be useful in breeding programs.
\end{abstract}

New Mexico leads the United States in chile production and processing (Lucier and Green, 1993). Chile (Capsicum annuum) is New Mexico's most valuable horticultural crop, with the processing-chile crop valued at more than $\$ 250$ million (New Mexico Dept. of Agriculture, 1992).

Rhizoctonia root rot of chiles is caused by Rhizoctonia solani [telemorph:Thanatephorus cucumeris (Frank) Donk], a fungal pathogen of many plant species (Sherf and MacNab, 1986; U.S. Dept. of Agriculture, 1960). On chiles, this soilborne fungus can cause seed decay, pre- and postemergence damping-off, wirestem, root rot, and necrotic spots on the hypocotyl or tap root (Sherf and MacNab, 1986). Rhizoctonia root rot is most severe on chile grown on clay soils; this disease becomes more problematic as chiles are planted in the same field for several consecutive years (Shannon and Cotter, 1986).

Several methods can be used to control $R$. solani, including crop rotation, fungicides, and resistant cultivars. Crop rotation provides only limited protection because the fungus survives as a saprophyte in the soil for several years (Hecker and Ruppel, 1977). Fungicides may reduce the disease incidence (Shannon and Cotter, 1986), but using chemicals raises environmental concerns. The most effective and environmentally safe method for controlling plant diseases is with resistant cultivars (Sherf and MacNab, 1986). To our knowledge, no commercial chile cultivars are known

Received for publication 17 Feb. 1994. Accepted for publication 18 Oct. 1994. A contribution of the New Mexico Agricultural Expt. Station, Las Cruces. The cost of publishing this paper was defrayed in part by the payment of page charges. Under postal regulations, this paper therefore must be hereby marked advertisement solely to indicate this fact.

${ }^{1}$ Research Assistant. Current address: PetoSeed Co., 37437 State Hwy. 16, Woodland, CA 95695.

${ }^{2}$ Professor. to be resistant to $R$. solani, presumably because no sources of resistance have been found. Therefore, we evaluated $C$. annuum and three other chile species to identify possible sources of resistance to rhizoctonia root rot.

Several investigators have developed screening techniques to identify sources of genetic resistance to $R$. solani in sugarbeet, (Beta vulgaris L.) (Ruppel et al., 1979), peas (Pisum sativum L.) (Shehata et al., 1981), carrots (Daucus carota L.) (Howard and Williams, 1976), snap beans (Phaseolus vulgaris L.) (Prasad and Weigle, 1970), and lima beans (Phaseolus limensis Macfady) (Warren et al., 1972). Soil infestation is the most common screening method. Shehata et al. (1981) reported that using corn (Zea mays Bonaf.) kernels as a soil infestation method gave better separation between resistant and susceptible pea genotypes than a cornmeal sand medium. Our report describes a reliable technique (Muhyi, 1990) that was developed at New Mexico State Univ., Las Cruces, to screen sources of genetic resistance to $R$. solani in four Capsicum species.

\section{Materials and Methods}

Samples of suspected $R$. solani-infected chile plants and seedlings were collected from several locations in New Mexico. Cultural and microscopic examination identified the fungal isolates as $R$. solani (Parmeter, 1970). The fungus was purified by the hyphal-tip technique. We identified anastomosis grouping (AG) of the R. solani isolates as described by Kronland and Stanghellini (1988). The AGtester isolates were obtained from Earl Ruppel (U.S. Dept. of Agriculture, Agricultural Research Service, Crops Research Lab., Fort Collins, Colo.). Each tester pairing was replicated two or three times, and the experiment was repeated once. Seven isolates belonged to AG 2-1, and 11 belonged to AG-4. The most aggressive, isolate PWB-25, was placed in AG-4.
Screening Capsicum germplasm for resistance to $R$. solani. Seventy-four accessions belonging to four Capsicum species (Table 1) from several origins were scored for resistance level (Muhyi, 1990). Several preliminary experiments established the adopted methods we described. Our experiment was a randomized complete-block design with 24 plants of each accession in each of two replicates. We used a postemergence inoculation method.

Chile seeds were surface-sterilized with $10 \%$ (w/v) trisodium phosphate for $30 \mathrm{~min}$ and then rinsed in distilled water (Rast and Stijger, 1987). Immediately following this treatment, the seeds were soaked for $15 \mathrm{~min}$ in $0.5 \%$ (v/v) sodium hypochlorite and then air-dried. Two chile seeds were placed in each cell (3.9 $\times 2.7 \times 5.5 \mathrm{~cm})$ of a 12-cell bedding plant container previously filled with a commercial peat-lite (RediEarth 3CF; Grace Sierra, Milpitas, Calif.) mixture. Each bedding plant container was placed in a $51.5 \times 25.5 \times 5.7-\mathrm{cm}$ plastic tray with a $1-\mathrm{cm}$ layer of vermiculite placed on the bottom of the tray. Three to four beads of a controlled-release fertilizer $(14 \mathrm{~N}$ $14 \mathrm{P}-14 \mathrm{~K}$ ) were placed on the surface of each cell. After planting, the trays were watered as needed to maintain good plant growth (usually daily). The trays were placed on a greenhouse bench where the air temperature was maintained at $28 \pm 1 \mathrm{C}$ day/15 $\pm 1 \mathrm{C}$ night. In this

Table 1. Diseases indices (DI) and percentage of resistant plants for the 19 most resistant and two most susceptible Capsicum accessions among 74 inoculated with $R$. solani isolate PWB-25.

\begin{tabular}{|c|c|c|c|}
\hline $\begin{array}{l}\text { Accession } \\
\text { identification }^{z}\end{array}$ & $\begin{array}{l}\text { Capsicum } \\
\text { species }^{\mathrm{y}}\end{array}$ & $\begin{array}{c}\text { DI } \\
(\mathrm{SD})^{\mathrm{x}}\end{array}$ & $\begin{array}{c}\text { Resistant } \\
\text { plants } \\
(\%)^{\mathrm{w}}\end{array}$ \\
\hline PI 439410 & C.b. & $2.9(2.9)$ & 70.8 \\
\hline PI 555611 & C.b. & $3.0(3.1)$ & 77.1 \\
\hline Long Chili & C.a. & $3.2(2.7)$ & 66.7 \\
\hline PI 167061 & C.a. & $3.3(3.0)$ & 71.3 \\
\hline PI 257130 & C.b. & $3.4(3.3)$ & 65.9 \\
\hline PI 273420 & C.b. & $3.5(3.3)$ & 63.9 \\
\hline Aji blanco & C.b. & $3.8(3.2)$ & 60.4 \\
\hline Giant Szegedi & C.a. & $3.9(3.8)$ & 60.6 \\
\hline NMCA1016 & C.a. & $3.9(3.3)$ & 56.3 \\
\hline NMCA1003 & C.a. & $3.9(3.7)$ & 56.1 \\
\hline NMCA5037 & C.b. & $4.2(3.5)$ & 59.6 \\
\hline NMCA1036 & C.a. & $4.3(3.5)$ & 56.8 \\
\hline Sandia & C.a. & $4.3(2.5)$ & 52.2 \\
\hline PI 171555 & C.a. & $4.3(3.4)$ & 59.1 \\
\hline PI 171559 & C.a. & $4.4(3.7)$ & 54.2 \\
\hline Tabasco & C.f. & $4.4(2.7)$ & 50.7 \\
\hline NMCA3009 & C.c. & $4.6(3.6)$ & 55.2 \\
\hline Santa Fe Grande & C.a. & $4.9(3.8)$ & 50.9 \\
\hline Florida VR2 & C.a. & $4.9(3.5)$ & 50.0 \\
\hline TAM Hildalgo & C.a. & $7.8(1.9)$ & 4.7 \\
\hline NMCA6002 & C.b. & $8.6(1.1)$ & 2.4 \\
\hline
\end{tabular}

${ }^{2} \mathrm{NMCA}=$ New Mexico Capsicum accession, $\mathrm{PI}=$ U.S. Dept. of Agriculture plant introduction.

${ }^{y}$ C. a. $=$ Capsicum annuum L., C.b. $=$ C. baccatum $\mathrm{L}$. C.c. $=C$. chinense Jacq., and C.f. $=C$. frutescens L. ${ }^{x}$ Mean of two replications (24 plants each) was calculated from an interaction phenotype scale $(0=$ healthy, $9=$ dead). DI: 0 to $3=$ resistant, 3 to $5=$ partially resistant, and 5 to $9=$ susceptible.

wPercentage of resistant plants is equal to the sum of interaction phenotype classes $0,1,2$, and 3 divided by the total and the result multiplied by 100 . 
successful screening protocol, placing the inoculated plants on a greenhouse bench was adequate environmental control to identify chiles resistant to $R$. solani.

Inoculum preparation. Corn kernels were soaked in tap water for $48 \mathrm{~h}$ and rinsed in running tap water for $15 \mathrm{~min}$. Then, the kernels (115 to $120 \mathrm{~g}$ wet weight) were placed in a 250-ml, wide-mouth Erlenmeyer flask. Each flask received 15 to $20 \mathrm{ml}$ distilled water and was autoclaved for $20 \mathrm{~min}$ at $121 \mathrm{C}$. After autoclaving, we placed three hyphal plugs (1 $\mathrm{cm}$ in diameter) of $R$. solani AG-4 (PWB-25) into each flask. The flasks were incubated at $23 \pm 1 \mathrm{C}$ for 2 weeks and then shaken by hand every 4 to 5 days. The colonized corn kernels then were used to infest the soil.

At the three to four true-leaf stage, two infested corn kernels were placed in the soil at a 2-cm depth next to the seedling but not touching the seedling. The seedlings were evaluated 20 days after the postinoculation treatment using the following interaction phenotype scale to rate the length (in millimeters) of superficial necrotic lesions on hypocotyls or tap roots: $0=$ no lesions; $1=1$ to $2 ; 3=3$ to $5 ; 5=6$ to 10 , sometimes girdling; $7=11$ to 30 , girdling, stunting of plant, leaf dropping; $9=$ death of seedlings. Even numbers were used to assess intermediate responses. To quantify the disease, a disease index (DI) was calculated

using the following formula: $\mathrm{DI}=$

where $\mathrm{i}=$ interaction phenotype class ( 0 to 9 ), $j=$ number of plants/class, $n=$ total number of plants. When scoring the Capsicum germplasm, the following DI categories were considered: 0 to $3=$ resistant, $>3$ to $5=$ partially resistant, $>5$ to $9=$ susceptible.

The percentage of resistant plants was calculated by adding the number of plants in the resistant category, then dividing by the total number of plants, and multiplying the product by 100 .

\section{Results and Discussion}

Resistance to $R$. solani varied widely among the Capsicum accessions, indicating a range in genetic variability for rhizoctonia root-rot resistance. With the postemergence inoculation technique, there were significant differences $(P \leq 0.0001)$ among the 74 Capsicum accessions in their response to isolate PWB-25. The percentage of resistant plants was highly correlated with the DI $(r=-0.97, P \leq 0.0001)$. We list (Table 1) DIs and the percentage of resistant plants only for the 19 accessions most resistant to rhizoctonia root rot and two susceptible accessions. DI ranged from 2.9 to 8.6. The most resistant chile accessions, PI 439410 and PI 555611, were C. baccatum.

Because it was sufficiently rigorous to separate resistant and susceptible individuals, the postemergence method was chosen to screen chile accessions. The $C$. baccatum accessions are considered resistant to rhizoctonia root rot, having mean disease indices $<3.1$ and the highest percentage of resistant plants. However, introgression of resistance from these accessions into C. annuum will be difficult due to $\mathrm{F}_{1}$ sterility (Greenleaf, 1986). The C. annuum accessions, 'Long Chili' (a Korean hybrid) and PI 167061, had $67 \%$ and $71 \%$ resistant individuals, respectively. The high proportion of resistant plants makes these accessions useful for introducing $R$. solani resistance into $C$. annuum cultivars. In addition, several $C$. annuиm accessions contained a notable percentage of resistant plants, so selection within a cultivar could result in an improved cultivar.

\section{Literature Cited}

Greenleaf, W.H. 1986. Pepper breeding, p. 67-134. In: M.J. Bassett (ed.). Breeding vegetable crops. AVI, Westport, Conn.

Hecker, R.J. and E.G. Ruppel. 1977. Rhizoctonia root rot resistance in sugarbeet: Breeding and related research. J. Amer. Soc. Sugar Beet Technol. 19:246-256.
Howard, R.J. and P.H. Williams. 1976. Methods for detecting resistance to pythium and rhizoctonia root diseases in seedling carrots. Plant Dis. Rpt. 60:151-156.

Kronland, W.C. and M.E. Stanghellini. 1988. Clean slide technique for the observation of anastomosis and nuclear condition of Rhizoctonia solani. Phytopathology 78:820-822.

Lucier, G. and C. Green. 1993. Vegetable and specialties situationand outlook report.CommodityEcon. Div., Econ. Res. Serv., U.S. Dept. Agr., Washington, D.C.

Muhyi, R.I.A. 1990. Developing single and multiple pathogen inoculation techniques on pepper seedlings (Capsicum spp.). PhD Diss., New Mexico State Univ., Las Cruces.

New Mexico Department of Agriculture. 1992. Chile, p. 70-71. In: New Mexico agricultural statistics. U.S. Dept. of Agr., New Mexico Agr. Stat. Serv., Las Cruces, N.M.

Parmeter, J.R. 1970. Rhizoctonia solani: Biology and pathology. Univ. of California Press, Berkeley.

Prasad, K. and J.L. Weigle. 1970. Screening for resistance to Rhizoctonia solani in Phaseolus vulgaris. Plant Dis. Rpt. 54:40-44.

Rast, A.Th.B. and C.C.M.M. Stijger. 1987. Disinfection of pepper seed infected with different strains of Capsicum mosaic virus by trisodium phosphate and dry heat treatment. Plant Pathology 36:583-588.

Ruppel, E.G., C.L. Schneider, R.J. Hecker, and G.J. Hogaboam. 1979. Creating epiphytotics of rhizoctonia root rot and evaluating for resistance to Rhizoctonia solani in sugarbeet field plots. Plant Dis. Rpt. 63:518-522.

Shannon, E. and D. Cotter. 1986. Chile disease control. Coop. Ext. Serv., New Mexico State Univ., Las Cruces. Circ. 400 W-12.

Shehata, M.A., D.W. Davis, and N.A. Anderson. 1981. Screening peas for resistance to stemrot caused by Rhizoctonia solani. Plant Dis. 65:417-419.

Sherf, A.F. and A.A. MacNab. 1986. Vegetable disease and their control. Wiley, New York.

U.S. Department of Horticulture. 1960. Index of plant diseases in the United States. Crops Res. Div., Agr. Res. Serv., U.S. Dept. of Agr., Agr. Hdbk. 165.

Warren, H.L., R.M. Helfrich, and V.L. Blount. 1972. Evaluation of lima bean varieties and selections for resistance to Rhizoctonia solani. Plant Dis. Rpt. 56:268-270. 